\title{
Appreciation of Peacock Dance With Field Trip Method
}

\author{
Tresna Noventy Mikdar* \\ Program Studi Pendidikan Seni \\ Universitas Pendidikan Indonesia \\ Bandung, Indonesia \\ *tresnanoventy@gmail.com
}

\begin{abstract}
The aim of writing this article is to discuss the learning process of peacock dance appreciation using the field trip method. This research method used a descriptive method with qualitative approach. The research data is presented by using descriptive statistics in the percentage form. Data collection techniques used observation, interviews, tests, literature study and documentation study. The results of the study showed that the level of students' appreciation increased significantly. And the result indicates the students become more active, able to observe, appreciate and could evaluate the dance that is appreciated, named the peacock dance.
\end{abstract}

\section{Keywords-appreciation, traditional dance, field trip method}

\section{INTRODUCTION}

Ideally, the teacher in the classroom should be able to master the classrooms' condition to create a conducive classroom atmosphere. Thus, the teacher must be able to apply learning methods which is well worked in accordance with the classroom conditions and the characteristics of students. Field trip according to Suryobroto is teaching and learning activities by visiting actual objects that have something to do with certain lessons [1]. According to Sutikno states that learning method is the way to present lessons carried out by teacher in order to achieve the learning process on students [2]. This is in line with the opinion about the teaching method put forward by Sudjana, the learning method is the method used by the teacher in making relationships with students during the teaching process [3]. Based on the above opinion, it can be concluded that the learning method can be interpreted as a method used to implement plans that have been prepared in the form of real and practical activities to achieve learning objectives, this can encourage teachers to choose appropriate learning methods according to student's conditions so that the material given by the teacher can be well absorbed. Learning methods are currently developing and can be used as a reference in the teaching and learning process, including the lecture method, question and answer method, training method, simulation method, field trip method, and others. A field trip is not just for recreation, but for learning or deepening the lesson by seeing the reality [4]. According to Sagala, the field trip method is an excursion carried out by students to complete certain learning experiences to complement an integral part of the school's curriculum [5]. Through field trips as a learning method, students under the teacher's attention will visit certain places with the intention of learning. This is similar to Mursid's opinion [6], the field trip method is a way of presenting learning material by taking the students directly to the studied outside objects. Based on this opinion, the Field Trip method is a way of teaching and learning that is carried out outside of school by inviting students to visit a place to study the material in depth and more meaningfully. The aims of using this field trip method are as follows [7]: (1) By implementing field trip method, the students hoped to be able to get direct experience from the object they see, (2) appreciate someone's task / job then ask questions directly, therefore they are able to overcome the problems faced in lessons, as well as general knowledge, (3) they can see, hear, research and try what they are facing, so they can take conclusions, at the same time they can learn another lesson. Teachers and committees on field trip activities must analyze the sources that will be used as a place to visit and must be adjusted to the learning curriculum and learning objectives. Learning a dance in elementary school, it is not only developing psychomotor but also improving cognitive and affective abilities. Suprijanto argues that the advantages of field trips are as follows [8]: (1) Field visits and field trips provide opportunities to gather new experiences and information; (2) Objects can be observed in their original form, namely threedimensional objects, colors, and observable movements; (3) Members' interest and accuracy can be grown; (4) Opportunities can be given to participants to learn while working; (5) An observable and experienced procedure could be applied by participants, etc. Isjoni states that the weakness of the field trip method is that field trips are usually carried out outside of school so that they require quite a long distance then they require transportation, require costs for transportation and entrance tickets, take a lot of time which shouldn't disturb their learning activities in schools, and safety for students and teachers [9]. There are also stages of implementation according to Hidayati are as follows [10]: (1) the preparation stage; (2) implementation stage; and (3) the follow-up stage of field trip implementation after returning to the place. 
Based on preliminary observations on fifth grade students at SD Negeri 3 Padaherang, the occured problems were learning in the classroom was very passive and conventional also more focused on teacher as the center. Classroom learning only focused on theory, there is a lack of practical activities to appreciative the implementation of teaching and learning activities such as watching a live performance or via video. In learning dance, grade $\mathrm{V}$ students are less able to appreciate the dance, it can be seen from the lack of attention of students to the explanation given by the teacher when giving appreciation material, students seemed confused and didn't understand what to take from the appreciation form, students were less active when having question time in the learning process, students had not been able to perform analysis, selection, criticize, and the students' weak ability to conclude learning material and do assignments which showed that students are less able to observe, appreciate and evaluate a dance work. Therefore, the field trip method can be used as an alternative to overcome the problem of student's weaknesses on appreciation of a dance work.

\section{METHODS}

This research method used a descriptive method with a qualitative approach. The research data is presented using descriptive statistics in the form of a percentage. Data collection techniques used observation, interviews, tests, literature study and documentation study.

\section{RESULTS AND DISCUSSION}

Based on research found in the field, researcher could obtain complete data about students' appreciation. When researcher conducted research at SD Negeri 3 Padaherang, researcher made preliminary observations about the learning process of dance in class $\mathrm{V}$. The results that the researcher got from the results of these observations showed that students' appreciation abilities were badly demanded improved, it could be seen from the students' movements. during the learning process, some students looked indifferent during the learning process also there were even some students busy chatting with their friends. Weak appreciation of students can also be seen when filling out a questionnaire about understanding appreciation in the aspect of observing, appreciating and evaluating, students were not working independently, there were some students disturbed their friends, some even opened notebooks. The questionnaire given regarding the aspects of observing, living and evaluating the results was categorized as sufficient. From the results of these preliminary observations there is a mismatch between the results of the questionnaire and the results of the observations, the results of the questionnaire are categorized as adequate, but when they were filled in, some students seemed interdependent, disturbed their friends and even opened notebooks, this showed that students' understanding of appreciation is still weak. Not only factors from students, but also factors from teachers also have an effect because teachers never have a follow-up action when appreciating, only observing. Based on these problems, ideally the teacher provides material on how to appreciate and with well preparation the students with slow understanding will do the task maximally, since all elementary school students are still children who still need guidance.

Based on the manifestation of student behavior in learning, the most important thing that affects students' appreciation abilities is teacher competence. The lack of teaching materials for teachers in the learning process of dance makes students interested in learning dance. After conducting interviews by researcher on students, the researcher obtained data that students did not like art, especially traditional dance. This is due to the lack of students 'knowledge of traditional dance and students' lack of experience in dance practice. If a cultural arts teacher has competence, the teacher will not only rely on the material in the book, but the arts and culture teacher will know how to combine the material contained in basic competencies and things that are important outside the basic competencies that students must know.

After the researcher knows this situation, hopefully in further learning the art of dance through the field trip method, students are invited to do field trips and visit Hiroshy dance studios with the aim of carrying out appreciation activities. When the field trip method was applied in learning dance, the researcher found that there were many changes in behavior during the learning process. If all this time students appreciate only seeing it without any follow-up, then when learning dance through the field trip method students will not be confused when given assignments and students will not be too bored with teaching material that is constantly on the source book. Not only that, if students' learning of dance is accustomed to learning to think rationally and to be critical, students will not find out the difficult to observe, appreciate and evaluate a dance work.

The importance of this appreciation apart from being used as a stimulus, appreciation is also included in the basic competence in using the Education Unit Level Curriculum (KTSP). The level of appreciation of a student for the value of a work depends on the level of understanding and learning experience. If students are accustomed to appreciating, students will learn to give appreciation to a dance work and students will learn in terms of rational and critical thinking. Therefore, students no longer have the opinion that appreciation is just an activity that only watches one dance work.

Learning dance through the field trip method is carried out by visiting the Hiroshy dance studio and appreciating the peacock dance as the material. At the first meeting held after recess, the teacher carried out the initial activities, then the teacher explains the learning to be carried out, the teacher and students carry out field trip activities. After arriving at the Hiroshy dance studio, students appreciated the peacock dance peforming, the students looked very enthusiastic when appreciating the peacock dance. After the appreciation is complete, the teacher directs and gives students the opportunity to look for dance and asks the dancers what they do not know. 
After finishing interviewing the dancers, then the students and the teacher returned to school. When they arrive in class, the teacher and students ask questions related to the things they found during the process of appreciating the peacock dance. At the second meeting, the teacher carried out the initial activities. Before appreciating again, the teacher repeats the previous lesson. Then the students appreciated the peacock dance, when they appreciated the students, they found and saw. Then, a question and answer session was conducted related to what the students found and analyzed, furthermore the teacher explained about the peacock dance material, and the teacher asked for comments about the material. The teacher divides into five groups then the students are given the opportunity to demonstrate the basic movements of the peacock dance and practice with dancers conditioned by the teacher. During the practice of dancing, the teacher always monitors the students, so they don't joke, the students really take part in the practical activities, after that the students in groups present the basic movements they have learned. The teacher reviews the material that has been studied and at the end the test is carried out by filling in test questions.

In the process of learning dance through the field trip method, students seemed enthusiastic when learning outside the classroom, especially when appreciating the peacock dance, students focused on what they saw and then recorded and analyzed. Students who are not satisfied with their findings then conduct interviews with the dancers. When the teacher explains the material, students focus on paying attention. The students were enthusiastic by themselves wanting to do dance practice activities.

Based on the results of this study, it is true that this research only focused on the ability to appreciate in terms of observing, appreciating and evaluating. By applying the field trip method, it will help to increase students' appreciation of traditional dance. According to the results of research in the field after learning dance through the field trip method, the students' appreciation skills increased significantly. After learning dance through the field trip method, the researcher gave a questionnaire and test questions. The results of filling out the questionnaire in the aspect of observing, living and evaluating are categorized as good. Then the students are able to answer the test questions well, this can be seen from the students' ability in doing the test questions based on the three aspects of appreciation in learning dance. These aspects include observing, appreciating and evaluating a dance work. From the aspect of observing, it shows that students can find and analyze all the supporting elements of dance. From an appreciative aspect, it shows that students can assess the two good and bad sides of a show and can find two messages contained in the dance that are appreciated. While the evaluation aspect shows that students can name all the supporting elements of the dance and can conclude well the results of the performance which they appreciate.

\section{CONCLUSION}

The field trip method is one of the learning methods that can be used to help learning the art of dance especially in learning appreciation. In this study, appreciation learning using the field trip method only focus on the aspects of observing, appreciating and evaluating a dance, namely the peacock dance. The results of this study show that appreciation learning activity looks significant after the application of the field trip method. From the aspect of observing, it shows that students can find and analyze all the supporting elements of dance. From an appreciative aspect, it shows that students can assess the two good and bad sides of a show and can find two messages contained in the dance that are appreciated. While the evaluation aspect shows that students can name all the supporting elements of the dance and can conclude well the results of the performance which they appreciate.

\section{REFERENCES}

[1] B. Suryobroto, Mengenal Metode Pengajaran di Sekolah dan Pendekatan Baru dalam Proses Belajar-Mengajar. Yogyakarta: Amarta, 1986.

[2] S. Sutikno, Belajar dan Pembelajaran. Bandung: PT RefikaAditama, 2009

[3] N. Sudjana, Dasar-Dasar Belajar Mengajar. Bandung: PT. Remaja Rosdakarya Offset, 2005.

[4] I. Iskandar, Metodologi Pembelajaran. Banten: LP3G, 2012.

[5] S. Sagala, Konsep dan Makna Pembelajaran. Bandung: Alfabeta, 2007.

[6] M.A. Mursid and N. Nur, Belajar dan pembelajaran PAUD. Bandung: Remaja Rosdakarya, 2015

[7] R. Rosetiyah, Strategi Belajar Mengajar. Jakarta: Rineka Cipta, 2008.

[8] H. Suprijanto, Pendidikan Orang Dewasa. Jakarta: Bumi Aksara, 2008

[9] I. Isjoni, Pembelajaran Visioner Perpaduan Indonesia-Malaysia. Yogyakarta: Pustaka Pelajar, 2007

[10] H. Hidayati, Pendidikan Ilmu Pengetahuan Sosial di Sekolah Dasar Yogyakarta: UNY, 2004. 